\title{
Eocene biogenic silica accumulation rates at the Pacific equatorial divergence zone
}

\author{
Ted C. Moore Jr., ${ }^{1}$ Richard D. Jarrard, ${ }^{2}$ Annette Olivarez Lyle, ${ }^{3}$ and Mitch Lyle ${ }^{3}$ \\ Received 2 July 2007; revised 25 October 2007; accepted 12 December 2007; published 15 April 2008.
}

[1] A synthesis of Eocene biogenic silica accumulation rates in the equatorial zone of the Pacific shows several relatively broad maxima spaced a few million years apart and extending from the uppermost Eocene into the lower Eocene. There is a distinct, step-like decrease in biogenic silica mass accumulation rate at $38.5 \mathrm{Ma}$ (just below the top of $\mathrm{C} 18 \mathrm{n} .1 \mathrm{n}$ ), which appears to be related to changes in oceanographic conditions in the eastern equatorial region. Eocene biogenic silica accumulation rates in the equatorial Pacific are distinctly lower than those in the Neogene. A comparison of Eocene accumulation rates and known areas of open ocean biogenic silica deposition with those in the more modern world leads us to conclude that there is no need to call upon an increased supply of dissolved silica to the world ocean to account for the siliceous-rich deposits of the Eocene.

Citation: Moore, T. C., Jr., R. D. Jarrard, A. Olivarez Lyle, and M. Lyle (2008), Eocene biogenic silica accumulation rates at the Pacific equatorial divergence zone, Paleoceanography, 23, PA2202, doi:10.1029/2007PA001514.

\section{Introduction}

[2] The Eocene biosiliceous oozes of the tropical Pacific are an easily recognizable sediment type having a reddish brown color and sugary texture. These sediments are dominated by radiolarian tests, with traces of terrigenous debris, hydrothermal oxides, a few diatoms and little if any carbonate. The paucity of carbonate is a result of the very shallow Pacific calcite compensation depth (CCD) of the Eocene $(\sim 3300 \mathrm{~m})$ [Rea and Lyle, 2005, and references therein]. The dominance of radiolarian tests over those of diatoms is an enigma in that diatoms usually dominate siliceous-rich sediments of the Oligocene and Neogene. The opal-rich character of these Eocene sediments is commonly associated with the development of cherts within the sections.

[3] These unusual characteristics of Eocene radiolarian oozes have prompted some authors to puzzle over how so much silica could have been delivered to the sea floor during the middle and upper Eocene [e.g., Gibson and Towe, 1971; Mattson and Pessagno, 1971; Herman, 1972; Berggren and Hollister, 1974; McGowran, 1989]. Suggested answers to this question include increased volcanic activity, increased weathering, and lithospheric plate reorganizations that supplied additional silica to the world ocean.

[4] The problems facing many of these earlier works in addressing questions of silica flux to the sea floor were twofold. First, in the Pacific at least, the time control on sediment accumulation rates was rather poor [van Andel et al., 1975; Leinen, 1979a, 1979b] and the practical recovery

\footnotetext{
${ }^{1}$ Department of Geological Sciences, University of Michigan, Ann Arbor, Michigan, USA.

${ }^{2}$ Department of Geology and Geophysics, University of Utah, Salt Lake City, Utah, USA.

${ }^{3}$ Department of Oceanography, Texas A\&M University, College Station, Texas, USA.

Copyright 2008 by the American Geophysical Union. 0883-8305/08/2007PA001514
}

of complete Eocene sections was inhibited by pervasive chert deposits. Time control in the Atlantic was somewhat better [Thiede et al., 1981; van Andel et al., 1977]; however, cherts often impeded good recovery there as well. Thus previous works [e.g., McGowran, 1989; Thiede et al., 1981] have discussed the Eocene siliceous deposits in terms of the concentrations of biogenic (opaline) silica, as opposed to its mass accumulation rates (MAR), which normalizes concentration over a unit area and unit time. Second, obtaining accurate measurements of biogenic silica concentrations in sediments has been difficult and has given rise to several different measurement techniques and strategies, all of which have substantial uncertainty in both accuracy and comparability.

[5] In this paper we will focus on the results of Ocean Drilling Program (ODP) Leg 199, which drilled a transect of sedimentary sections at sites across the equatorial Pacific of the Eocene. These sites are ideal for this study because of the good recovery of unlithified Eocene sediments that are rich in well-preserved radiolarian microfossils. These sediments provide an excellent opportunity to elucidate biogenic sedimentation patterns of the Eocene equatorial divergence zone as a continuous record. The Leg 199 sites used in this study contain relatively minor occurrences of lithified sediment, primarily as chert. We did not measure or calculate mass accumulation rates for this source of silica, nor from the very base of the sections in which the biogenic silica has probably been removed by dissolution. Our reported results and interpretations reflect the silica that is biogenic in origin. We will compare the biogenic silica mass accumulation rates within these Eocene age sites to those rates at sites drilled across the corresponding Neogene equatorial Pacific on ODP Leg 138 (Figure 1).

\section{Methods}

[6] Biogenic silica concentrations of the radiolarian oozes, which characterize much of the sediments, were 


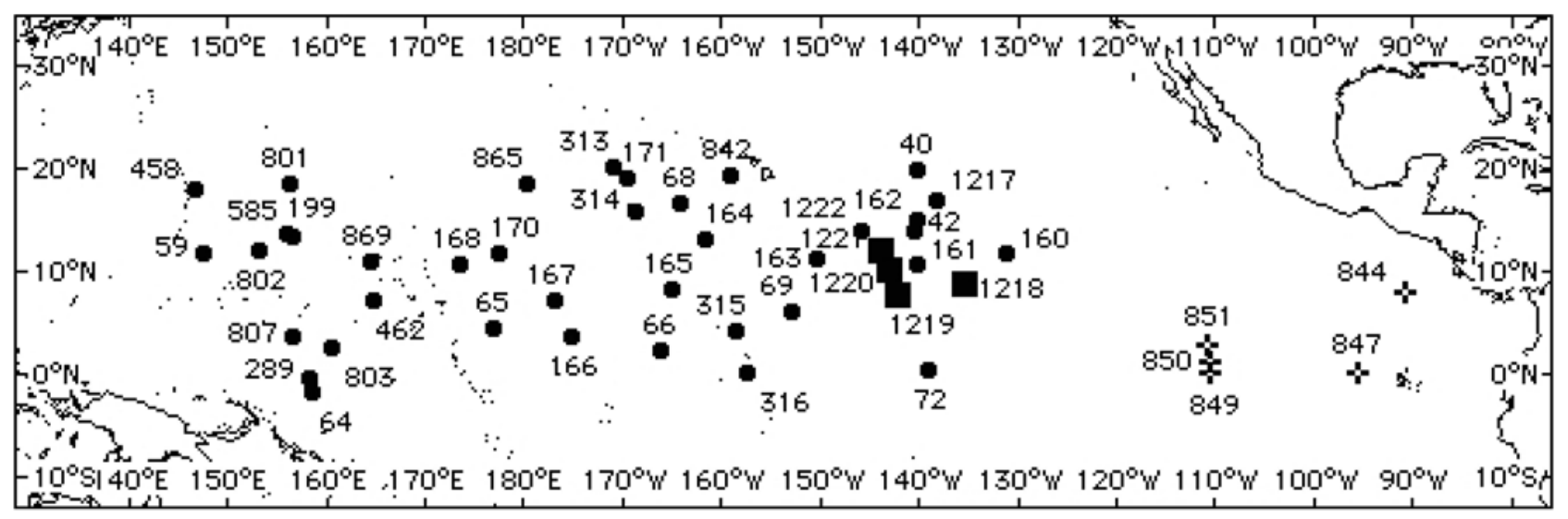

Figure 1. Location of DSDP and ODP drill sites used in this study. Plus signs mark ODP Leg 138 Sites used in determination of Neogene opal mass accumulation rates (MAR). Squares mark ODP Leg 199 sites used in determination of Eocene opal MAR. All other sites, including ODP Leg 199 sites, used in determining patterns of Eocene sediment accumulation rates (cf. Figures 6 and 7).

measured by the techniques described by Olivarez Lyle and Lyle [2002] and Vanden Berg and Jarrard [2002, 2004, 2006] for Leg 199 sediments, and as described by Farrell et al. [1995] for Leg 138 sediments. Both Olivarez Lyle and Lyle [2002] and Farrell et al. [1995] used modified versions of the Mortlock and Froelich [1989] wet alkaline extraction technique for measuring concentrations of biogenic silica, but with important differences as described later (see next paragraph). For Leg 138 sediments, an interlaboratory comparison presented by Farrell et al. [1995] showed that the biogenic silica percent values obtained by T. Janecek (using the wet alkaline extraction technique) and by M. Levitan (using an X-ray fluorescence spectroscopy technique) were very close, but were $4 \%$ to $6 \%$ lower than those obtained by Murray, who also used the Mortlock and Froelich [1989] technique. We have used the more numerous opal values produced by T. Janecek and M. Levitan [see Farrell et al., 1995] in our comparisons to the Eocene biogenic silica accumulation rates.

[7] For ODP Leg 199 Sites, Olivarez Lyle and Lyle [2005] and Lyle et al. [2005] used a modified version of the Mortlock and Froelich [1989] wet alkaline extraction technique with greatly improved results (as detailed by Olivarez Lyle and Lyle [2002]). The earlier technique often gives much lower estimates of biogenic silica content because $\mathrm{Na}_{2} \mathrm{CO}_{3}$ does not completely dissolve radiolarian tests, especially in radiolarian-rich Eocene sediments of Leg 199 [Olivarez Lyle and Lyle, 2002]. However, when $\mathrm{KOH}$ is the alkaline solution, dissolution is complete without the problem of leaching silicon from the clay mineral fraction (aluminosilicates). A comparison between the $\mathrm{KOH}$ method and that of Farrell et al. [1995] (using $\mathrm{Na}_{2} \mathrm{CO}_{3}$ ) was carried out in a Neogene section of ODP Site 1021 (not shown here) for sample pairs whose ages range between 5 and $13 \mathrm{Ma}$. The $\mathrm{KOH}$ leaching technique consistently gave higher estimates of opal concentrations, by a factor of 2 $( \pm 0.5)$ for the 34 Neogene samples analyzed (A. Olivarez Lyle, personal communication, 2007). Both reagents were found to leach silica from volcanic ash or glass, but these components were not an issue for Leg 199 sediments. For the purposes of data set comparisons and discussion of results, it is likely that the Neogene data from ODP Leg 138 underestimates biogenic silica, for reasons as discussed above and by Farrell et al. [1995].

[8] In both the Neogene and Eocene intervals, samples where obvious dissolution or precipitation had taken place were avoided to minimize diagenetic artifacts. The primary bias between the two data sets is caused by methodological differences. The Neogene biogenic silica data set of T. Janecek [see Farrell et al., 1995] is offset to lower values relative to the Eocene biogenic silica data set measured by Olivarez Lyle and Lyle [2005]. Therefore, the discrepancy between the Eocene and Neogene biogenic silica MARs is likely substantially greater than reported here because estimates of Neogene biogenic silica concentrations are too low, relative to the Eocene values obtained using the modified $\mathrm{KOH}$ technique.

[9] Vanden Berg and Jarrard [2002, 2004, 2006] estimated the mineralogy of Leg 199 sediments on the basis of reflectance spectroscopy at visible and near-infrared wavelengths. These data were used to calibrate a conversion of multisensor track physical properties and light spectroscopy data into percentages of opal, calcite, and terrigenous fraction, on the basis of multiple regression [Vanden Berg and Jarrard, 2006]. Comparison of their data for biogenic silica in the Eocene and lowermost Oligocene with direct geochemical measurements of Olivarez Lyle and Lyle [2005] reveals systematic bias within the reflectance spectroscopy data, probably attributable to insufficient local calibration standards for the spectroscopy-based mineralogy calculation. In the upper Eocene part of the section, where carbonate concentrations were very low, the reflectance spectroscopy technique overestimates carbonate concentrations and underestimates biogenic silica concentrations (Figures 2a) and 2b. We adjust the estimated Eocene opal fraction determined by Vanden Berg and Jarrard by using the measured carbonate fraction rather than that estimated by light spectroscopy. The resultant adjusted opal estimation ( 1 - [estimated terrigenous + measured carbonate]) is much closer to values measured by the Olivarez Lyle and Lyle 

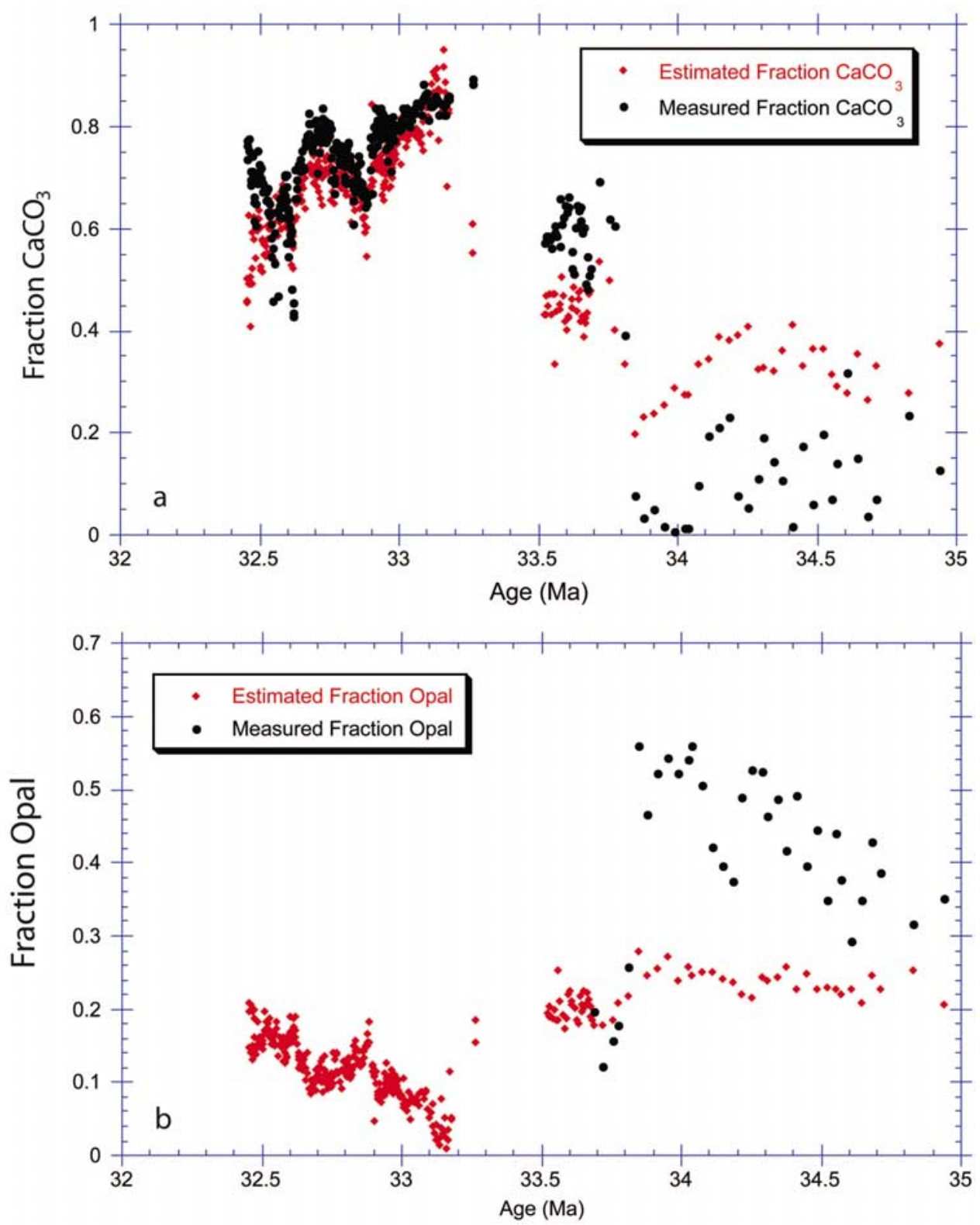

Figure 2. Estimated (a) carbonate and (b) opal fractions (using reflectance spectroscopy: see section 2) and measured carbonate and opal fractions (using chemical analysis) across the Oligocene-Eocene boundary at Site 1218 .

[2002] technique. Measurements on paired samples using the adjusted light spectroscopy and the revised wet chemical techniques agreed within 5\% (Figure 3). We have used these adjusted Vanden Berg and Jarrard [2006] estimates of biogenic silica concentrations as well as the Lyle et al. [2002] and Lyle et al. [2005] geochemical data set in this study. The former provides much more abundant and therefore higher-resolution data, whereas the latter are more accurate values of biogenic silica content, but the analyses were performed on fewer samples at a lower resolution. Dry bulk density values used in calculating mass accumulation rates (MARs) are as calculated by Olivarez Lyle and Lyle [2005].
[10] The other major obstacle to estimating biogenic silica accumulation in the Eocene has been the lack of well-dated stratigraphic control in the carbonate-free sections. The excellent recovery of sediments obtained on ODP Leg 199 and the good paleomagnetic stratigraphy allowed the development of a well-defined chronostratigraphy for the Eocene sections [Lyle et al., 2002; Parés and Lanci, 2004; Lanci et al., 2005], as well as over 140 first and last appearances of Eocene radiolarian species [Nigrini et al., 2006]. The paleomagnetic timescale for the Eocene has been adjusted by an initial attempt at tuning to Milankovitch frequencies in ODP Site 1218 [Pälike et al., 2006]. These paleomagnetic and biostratigraphic datums have been used in refining the early Oligocene and Eocene chronostratig- 


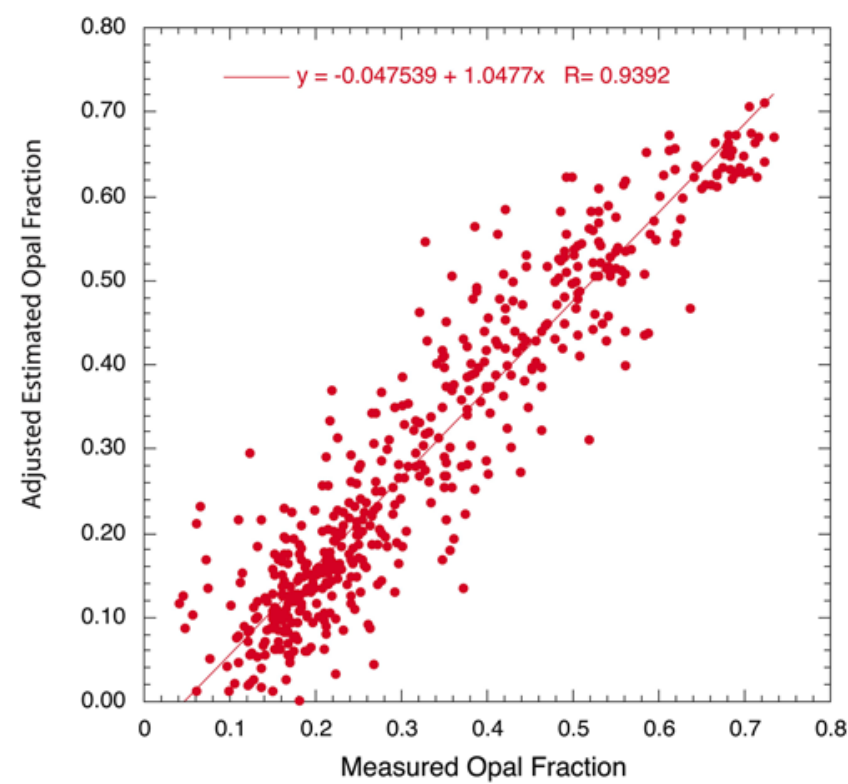

Figure 3. Measured opal fraction versus estimated opal fraction that is adjusted by using measured carbonate rather than carbonate estimated by reflectance spectroscopy in estimating the opal value (see section 2). Samples from the Eocene section of Site 1218.

raphy and in making the estimates of accumulation rates used in this paper. Wherever possible, calcareous nannofossil datums were used as well [Lyle et al., 2002]. These were particularly useful at the base of the sections where no biogenic silica was preserved.

[11] Moore et al. [2004] mapped the Neogene and Paleogene spatial patterns of sediment accumulation rates in the tropical Pacific, on the basis of available DSDP and ODP sites. They used an initial hotspot framework to determine paleolatitudes, but on the basis of the location of a narrow tongue of high accumulation rates normally associated with the equatorial divergence, they detected a second-order offset of this divergence from predicted paleolatitudes. The detection of this offset allowed a slight refinement of paleolatitudes. We use the Eocene subset of the data included by Moore et al. [2004], with the added use of radiolarian datums [Nigrini et al., 2006] to refine the stratigraphy and the revised Eocene rotated site locations of Moore et al. [2004] and Páres and Moore [2005].

[12] In this paper we consider biogenic silica accumulation rates only in those parts of the sections that were within $2^{\circ}$ latitude of the paleoequator at the time of deposition (Figures 1 and 4). These include data from ODP Leg 199 Sites 1218, 1219, 1220, and 1221. ODP Leg 138 sites that were within $2^{\circ}$ of the equator from 0 to $17 \mathrm{Ma}$ are as defined by Pisias et al. [1995]. These include data from ODP Sites $844(12-17.1 \mathrm{Ma}), 847$ (0-6.7 Ma), 849 (0-11.6 Ma), 850 $(0-11.9 \mathrm{Ma})$, and $851(3-12.5 \mathrm{Ma})$.

\section{Results}

[13] Biogenic silica mass accumulation rates within the equatorial divergence region for each of the ODP Leg 199 sites are shown in Figure 4 as a function of age. The sites are arranged according to latitude (Figure 1), and the interval of time during which each site was within $2^{\circ}$ of the paleoequator is shaded. Sites 1218 and 1219 appear the most similar. They are located at approximately the same modern latitude, with Site 1219 drilled on $~ 56$ Ma crust and Site 1218 on $\sim 42$ Ma crust. They both have comparatively high and variable biogenic silica accumulation rates in the lower Oligocene, with a minimum near the Eocene/Oligocene boundary. Sites 1220 and 1221, in contrast, migrated northward out of the equatorial zone earlier in the Eocene. These sites show fewer distinct peaks in biogenic silica accumulation, and in intervals older than about $46 \mathrm{Ma}$ are affected by poor recovery and the presence of chert layers. Vertical bars mark the main peaks in biogenic silica MAR, which are also shown in the averaged data for the equatorial zone (Figure 5). Note that some of these peaks are only seen in sites that are within the equatorial zone, whereas others are seen in sites that lie outside this zone (e.g., Sites 1220 and 1221). Also note that the biogenic silica MAR drops markedly at the base of some of the sections (e.g., Sites $1219,1220)$. All sites show a high degree of silica dissolution at the base of the sedimentary section.

[14] The oldest indication of a peak in biogenic silica flux rates is seen in Site 1220 between 50.5 and $51 \mathrm{Ma}$. This interval was not recovered at the other sites. There is also a hint of a biogenic silica flux peak in Site 1221 at $~ 49-$ $50 \mathrm{Ma}$, just above the deeper chert layers in this site. In younger intervals, more distinct peaks in biogenic silica flux rates are found near $46 \mathrm{Ma}$ (Site 1220); between $43-44 \mathrm{Ma}$ (Sites 1219, 1220, 1221); 40.5-41.5 Ma (Sites 1218, 1219, 1220, 1221); 38.5-39.5 Ma (Sites 1218, 1219, 1220, 1221); and at $35.5 \mathrm{Ma}$ (Site 1218).

[15] To better delineate the variation in biogenic silica accumulation rates near the equatorial divergence, biogenic silica accumulation rates were averaged over $20 \mathrm{Ka}$ within each site and then the value for each $0.02 \mathrm{Ma}$ increment was averaged in just those sites within the equatorial zone, which we have defined as within \pm 2 degrees of the paleoequator (Figures 4 and 5). Stratigraphic control used to calculate accumulation rates is indicated in Figure 5. In the section older than about $45 \mathrm{Ma}$, Figure 5 represents the average of data from only one site (Sites 1220 or 1221). In the younger section, data from two to three sites are averaged. The range of $20 \mathrm{Ka}$ averages for individual sites is shown as a shaded band around the plotted average of all the equatorial sites sampling each time interval. These averages show at least eight main Eocene biogenic silica accumulation events (ESAE 1-8; Figure 5 and Table 1) that can be identified in some, if not all, of the individual sites (cf. Figure 4). The oldest MAR peaks (ESAE 1,2) are not well defined, but they appear to be comparable in magnitude to subsequent ESAE 3 and 4 peaks (Figure 5 and Table 1).

[16] The next younger peak (ESAE 5) is comparatively broad and incorporates several more narrow peaks between 41.5 and $39.6 \mathrm{Ma}$ (Table 1). These finer-scale variations are not seen in every site (cf. Figure 4); however, as indicated by the shaded band surrounding the average values, the variability of measurements in this peak (particularly between 40.5 and $41.5 \mathrm{Ma}$ ) is large. ESAE 5 corresponds to the 


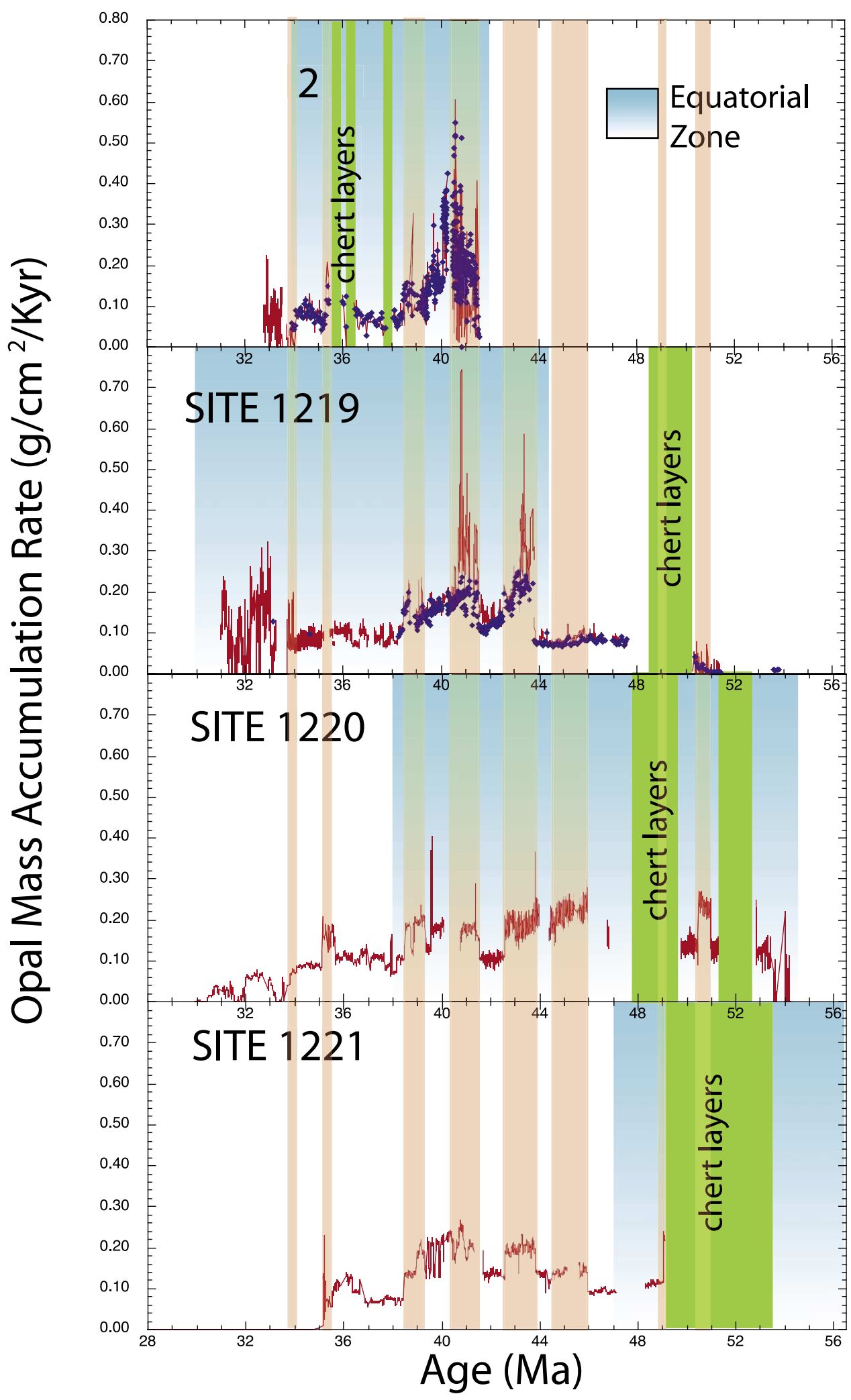

Figure 4. Opal MAR for the four ODP Leg 199 sites that were within $2^{\circ}$ of the paleoequator (equatorial zone) during the Eocene (based on Moore et al. [2004]). Solid red lines indicate adjusted estimates of opal MAR (see section 2). Blue diamonds indicate measured opal MAR. Intervals with chert layers indicated by green vertical bars in the plot of each site. Intervals representing times when each site was within the equatorial zone are indicated by shaded blue boxes. Major peaks in average opal MAR in the equatorial zone (Figure 5) indicated by shaded vertical bars extending through all sites. 


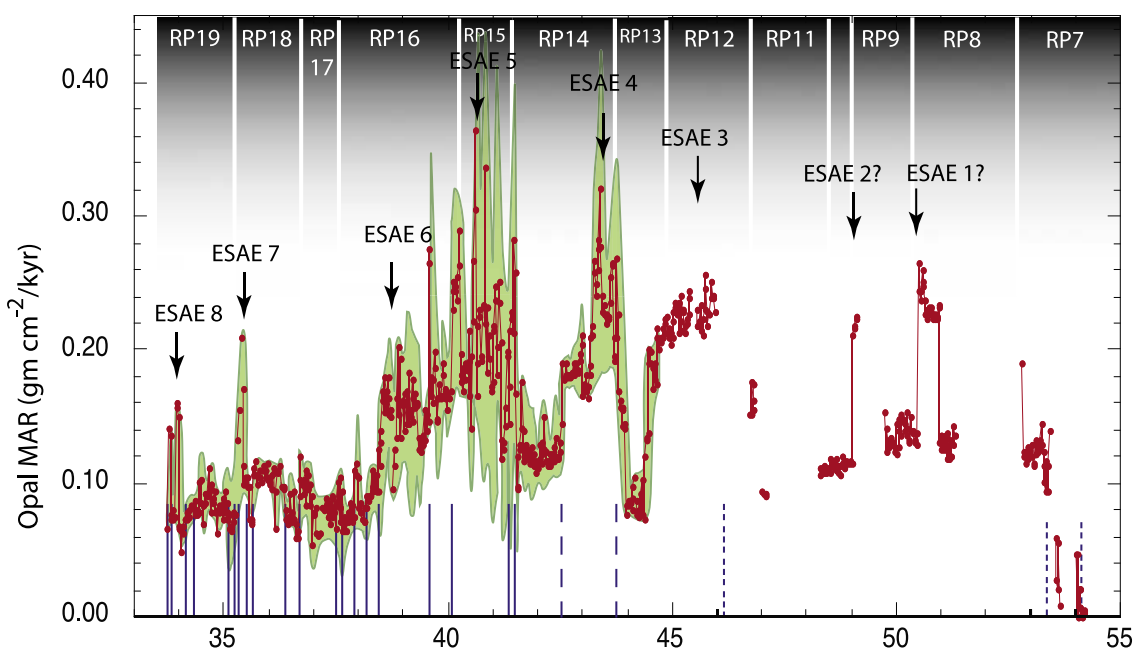

Figure 5. Averaged opal MAR for all sites within the equatorial zone during the Eocene, based on the data of Figure 4. Opal MAR was averaged for each $0.02 \mathrm{Ma}$ interval in each site, and then the average was taken for each 0.02 Ma for all sites in the equatorial zone. Shaded (green) band encompasses average values from individual sites. For the record older than $\sim 45 \mathrm{Ma}$, only one site (Site 1220 or Site 1221) is represented in the averaged data (cf. Figure 4). Chronostratigraphic control used in calculating accumulation rates is indicated by vertical lines at the base of the plot. Solid lines represent tuned magnetic chron ages [after Pälike et al., 2006]; dashed lines represent magnetic chron boundaries [Cande and Kent, 1995]; dotted lines represent biostratigraphic datums. Vertical white lines at the top of the plot indicate boundaries of radiolarian (RP) zones [from Nigrini et al., 2006].

most prominent Eocene peak in carbonate accumulation, Carbonate Accumulation Event 3 (CAE 3) [Lyle et al., 2005; Olivarez Lyle and Lyle, 2005, 2006]. This carbonate accumulation event, as well as the next younger event (CAE 4; Table 1), appears to be associated with times when colder waters (or higher ice volume) were influential and when higher biologic productivity occurred [Lyle et al., 2005; Olivarez Lyle and Lyle, 2005, 2006]. These authors noted, however, that the interval between these two carbonate events had a relatively high MAR of organic carbon as well as biogenic silica; thus, the lowcarbonate MAR between these two events was likely to be associated with carbonate dissolution (during a relatively warm interval) rather than reduced nannoplankton productivity. Indeed, average biogenic silica MAR (predominantly as zooplankton) remains relatively high throughout the interval between ESAE 5 and ESAE 6 (Figure 5 and Table 1). At the end of ESAE 6, however, average biogenic silica MAR drops sharply and only briefly recovers in ESAE 7 (35.5 Ma) and ESAE 8, just above the Eocene-Oligocene boundary (Figure 5).

[17] Although the longest documented interval of high (but variable) biogenic silica MAR occurs between 38.5 and $41.5 \mathrm{Ma}\left(\sim 0.18-0.20 \mathrm{~g} / \mathrm{cm}^{2} / \mathrm{ka}\right)$, background levels of biogenic silica MAR through the early and mid-Eocene are close to $0.12 \mathrm{~g} / \mathrm{cm}^{2} / \mathrm{ka}$. Near $38.5 \mathrm{Ma}$ biogenic silica flux rates drop to background levels near $0.08 \mathrm{~g} / \mathrm{cm}^{2} / \mathrm{ka}$. This abrupt change represents a 56 per cent decrease in biogenic silica MAR from the peak values of ESAE $6\left(0.18 \mathrm{~g} / \mathrm{cm}^{2} / \mathrm{ka}\right)$ and occurs within the continued mid-late Eocene cooling trend that comes after the Mid Eocene Climatic Optimum (MECO) of Bohaty and Zachos [2003]. However, the MAR of organic carbon in the uppermost middle and upper Eocene shows several peaks [Olivarez Lyle and Lyle, 2005, 2006], two of which are associated with ESAE 7 and 8 . These peaks in organic carbon MAR could relate either to sustained biologic productivity or to a decrease in the overall oceanic biologic metabolism rate as temperatures in the ocean cooled [Olivarez Lyle and Lyle, 2005, 2006].

[18] To see if there is some spatial pattern associated with the $38.5 \mathrm{Ma}$ drop in biogenic silica MAR, one can compare maps of average sediment accumulation rates in the tropical Pacific for the intervals 34-38 Ma (Figure 6) and 39-42 Ma (Figure 7). The sediments of this region contain some carbonate as well as biogenic silica (particularly on bathymetric highs in the western part of the region), and both

Table 1. Eocene Silica Accumulation Events From the Equatorial Pacific and Associated Carbonate Accumulation Events ${ }^{\mathrm{a}}$

\begin{tabular}{lccc}
\hline $\begin{array}{c}\text { Opaline Silica } \\
\text { Accumulation } \\
\text { Event }\end{array}$ & $\begin{array}{c}\text { Age, } \\
\text { Ma }\end{array}$ & $\begin{array}{c}\text { Average Peak } \\
\text { Rate, } \\
\text { gm } / \mathrm{cm}^{2} / \mathrm{ka}\end{array}$ & $\begin{array}{c}\text { Carbonate } \\
\text { Accumulation } \\
\text { Event }\end{array}$ \\
\hline ESAE 1? & $50-51$ & 0.25 & \\
ESAE 2? & $49-50$ & 0.23 & \\
ESAE 3 & $45-46$ & 0.24 & \\
ESAE 4 & $43-44$ & 0.28 & $\sim$ CAE 3 \\
ESAE 5 & $40.5-41.5$ & 0.33 & $\sim$ CAE 4 \\
ESAE 5a & 40.3 & 0.25 & $\sim$ CAE 6, 7 \\
ESAE 5b & 39.6 & 0.26 & \\
ESAE 6 & $38.5-39.3$ & 0.18 & \\
ESAE 7 & 35.4 & 0.17 & \\
EASE 8 & $33.7-34$ & 0.16 & \\
\hline
\end{tabular}

${ }^{\mathrm{a} E S A E}$ : Eocene Silica Accumulation Events (from Figure 5). CAE: Carbonate Accumulation Events (from Olivarez Lyle and Lyle [2005]). 


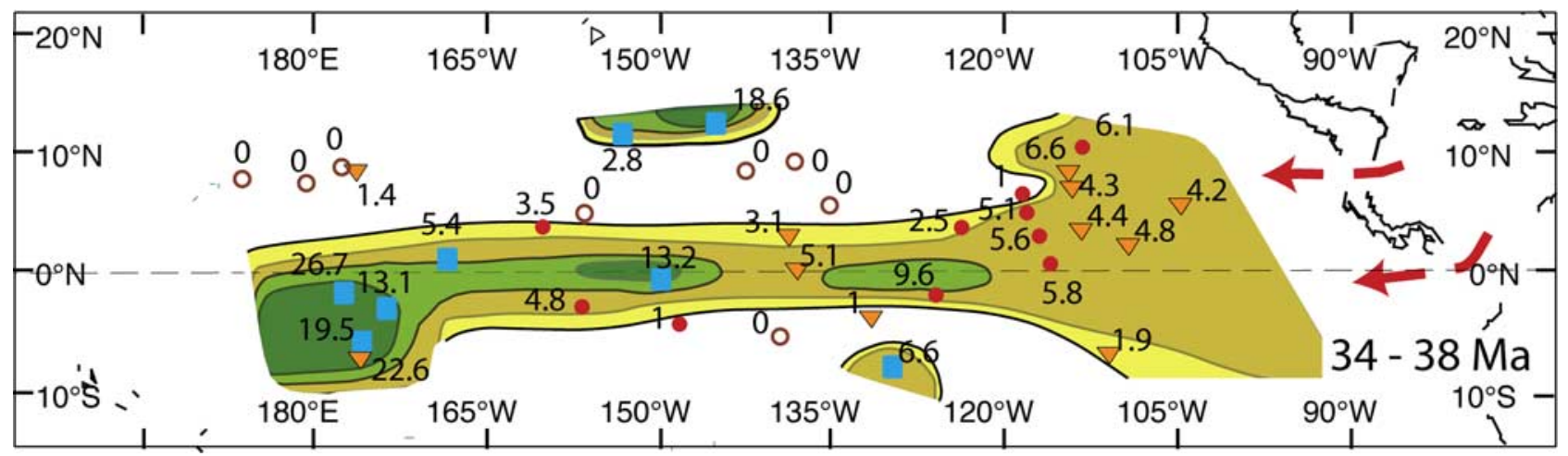

Figure 6. Sediment accumulation rates in the tropical Pacific during the interval of 34-38 Ma. Site locations relative to the geographic equator at $36 \mathrm{Ma}$, after Moore et al. [2004] and Parés and Moore [2005]. Numbers represent accumulation rates in m/Ma. Open circles mark sites with accumulation rates significantly less than $1 \mathrm{~m} / \mathrm{Ma}$. Filled circles mark sites with siliceous microfossils only; inverted triangles mark sites with both siliceous and calcareous microfossils; filled squares mark sites with calcareous microfossils only.

maps show a well-defined zone of high sediment accumulation rates associated with the equatorial divergence. The largest observed change is in the eastern tropical Pacific. Here, the older interval has nearly double the sediment accumulation rates of the younger interval.

[19] From these maps it appears that the sharp drop in the level of biogenic silica flux at $38.5 \mathrm{Ma}$ is likely to represent a distinct environmental change in the easternmost, highly productive part of the tropical Pacific. As such, this change should also be evidenced in the radiolarian assemblage. Changes in the rate of speciation are often used to denote changes in environmental conditions, and recent advances in the radiolarian stratigraphy of the Pacific Eocene [Nigrini et al., 2006] allow us to investigate this possibility. Figure 8 shows the number of radiolarian first and last appearance datums (FAD and LAD) binned in $0.5 \mathrm{Ma}$ increments of time. The largest peak in this simple measure of faunal turnover occurs at the Eocene-Oligocene boundary, where there are large changes in other planktonic assemblages as well as the radiolaria [e.g., Funakawa et al., 2006]. The second major peak occurs at $38.5 \mathrm{Ma}$ and coincides with the step change in biogenic silica flux. Known environmental changes cannot at this time be correlated to the oldest peak in FADs and LADs at $46 \mathrm{Ma}$ (Figure 8), and it may be an artifact of the sparse data in the older part of the sections studied (Sites 1219 and 1220).

[20] The difference between the maximum and minimum values of the average MAR of biogenic silica in the equatorial Pacific ranges over half an order of magnitude (Figure 5). Where recovered, the early Eocene rates do not appear greatly different from those of the middle Eocene; however, the lower middle Eocene and lower Eocene are rarely well recovered in the Pacific. In part, this is due to the prevalence of cherts in this portion of the section, affecting both the recovery and preservation of the radiolarian oozes and siliceous clays. One of the most surprising results from these data is that the upper Eocene appears to have the lowest overall MAR of biogenic silica. The common

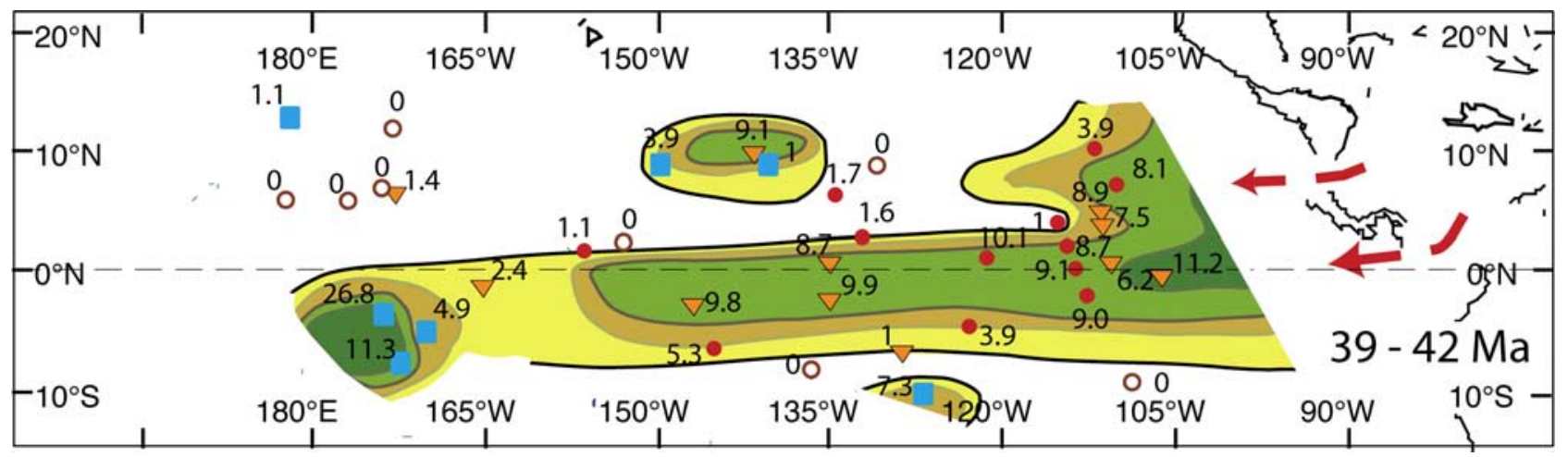

Figure 7. Sediment accumulation rates in the tropical Pacific during the interval of 39-42 Ma. Site locations relative to the geographic equator at $41 \mathrm{Ma}$, after Moore et al. [2004] and Parés and Moore [2005]. Numbers represent accumulation rates in m/Ma. Open circles mark sites with accumulation rates significantly less than $1 \mathrm{~m} / \mathrm{Ma}$. Filled circles mark sites with siliceous microfossils only; inverted triangles mark sites with both siliceous and calcareous microfossils; filled squares mark sites with calcareous microfossils only. 


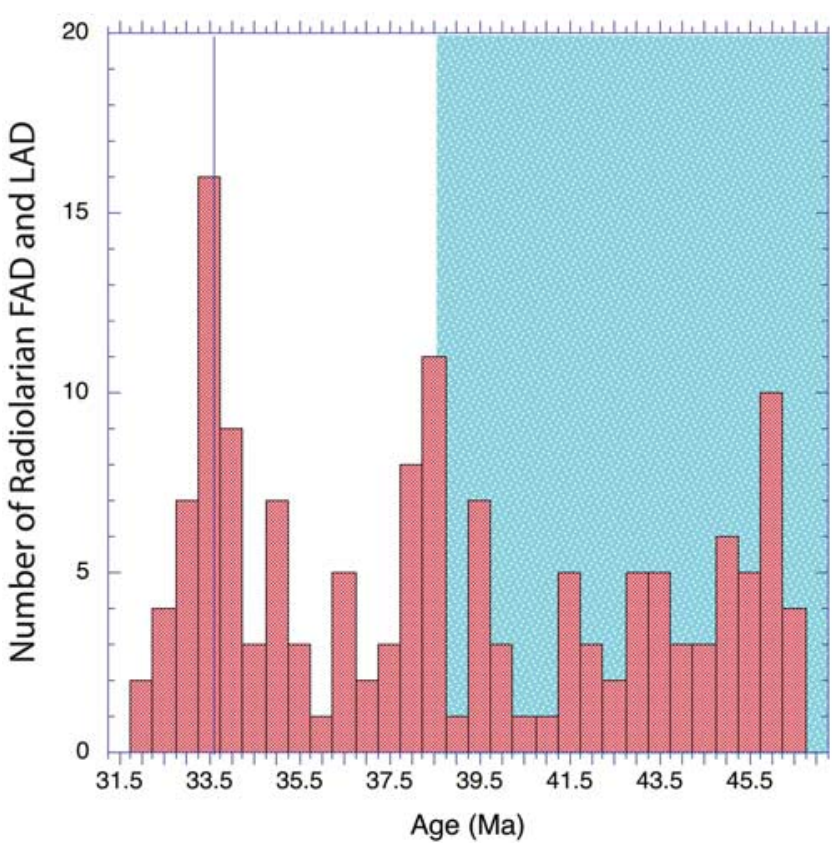

Figure 8. First and last appearance datums of radiolarian species binned in $0.5 \mathrm{Ma}$ intervals (data from Nigrini et al. [2006]). The Eocene-Oligocene boundary is marked by a vertical line. The shaded area marks that part of the Eocene with higher opal MAR.

occurrence of hiatuses at the Eocene-Oligocene boundary has in the past made flux rates in this interval difficult to estimate. Although small undetected breaks in the records of Sites 1218 and 1219 may exist, the good recovery, the improved analytical method in measuring biogenic silica, and the paleomagnetic control at these sites [Parés and Lanci, 2004] have largely overcome this problem.

[21] Having established a history of biogenic silica MAR in the Eocene, we next contrast the sedimentation rates in this "most siliceous rich" part of the Cenozoic section in the tropical Pacific with comparable measurements from the Neogene (Leg 138). ODP Leg 138 drilled a transect of sites in the eastern equatorial Pacific that recovered complete sections from the middle Miocene to Recent [Mayer et al., 1992]. For ODP Sites 844, 847, 849, 850 and 851, we have averaged MARs over $0.1 \mathrm{Ma}$ intervals. For each of those intervals, we then averaged the results for all sites that lay within $2^{\circ}$ of the paleoequator (Figure 9).

[22] This Neogene record is of a comparable length and duration (although lower resolution) to that from the Eocene equatorial Pacific $(\sim 17 \mathrm{Ma})$ and exhibits several of the same characteristics. It shows several sharp peaks in biogenic silica MAR as well as a shift in the average background accumulation rate, in this case occurring in the early Pliocene ( 4.4 Ma). However, there is a marked difference in the magnitudes of the biogenic silica accumulation rates in the Neogene versus the Eocene. The average Neogene biogenic silica MAR from $0-4.4 \mathrm{Ma}\left(\sim 0.20-0.25 \mathrm{~g} / \mathrm{cm}^{2} / \mathrm{ka}\right)$, though distinctly less than in the older part of that record, is approximately equal to the peak rates associated with ESAE 1 through -4 , and exceeds the peak rates associated with ESAE 6,7 , and $-8\left(0.16-0.18 \mathrm{~g} / \mathrm{cm}^{2} / \mathrm{ka}\right)$. It is more than twice the average biogenic silica MAR in the upper Eocene. Similarly, the average rate in the older Neogene section $\left(\sim 0.30 \mathrm{~g} / \mathrm{cm}^{2} / \mathrm{ka}\right)$ is about twice that of the average lower to middle Eocene biogenic silica MAR. The peak values of the mid to lower Eocene (ESAE 1-6) are approximately equal to the background values in the older Neogene. These differences in Eocene versus Neogene biogenic silica MAR are likely to be minimum estimates because of the more effective dissolution technique used by Olivarez Lyle and Lyle [2002] on the Eocene section (see section 2). As a result both Neogene biogenic silica concentrations and accumulation rates (as well as the differences between Neogene and Eocene biogenic silica MAR) are likely to be underestimated. Although the Eocene section is noted for its siliceous-rich lithology, the rate at which biogenic silica was collecting in the eastern equatorial Pacific during the Eocene was distinctly lower than in the same region during the mid to late Neogene.

\section{Discussion and Conclusions}

\subsection{Eocene-Neogene Contrast}

[23] The Eocene has a reputation as the time of the "silica-rich ocean" [e.g., McGowran, 1989]. This reputation stems from the fact that a very shallow CCD in the Pacific Ocean prohibited carbonate deposition and left most pelagic sediments dominated by biogenic silica and clay. Our results, however, show that in terms of the MAR of biogenic silica beneath the equatorial Pacific divergence, the Eocene biogenic silica flux to the sea floor was much less than that seen in the Neogene. This is true even though the equatorial zone of higher accumulation rates remains welldefined through much of the Eocene and a secondary zone of higher accumulation rates is found northward of the Pacific Eocene equator (Figures 6 and 7) [Moore et al., 2004]. The northern zone of higher rates is not seen in sections younger than Oligocene [Moore et al., 2004] and is thought to represent upwelling associated with passage of waters through the northern Panamanian gateway and divergence at the North Equatorial Current and North Equatorial Countercurrent boundary.

[24] This is not the only contrast that can be made between the Neogene and Eocene siliceous sediments and between the oceans of these two times. In the Neogene the siliceous fraction of pelagic sediments is dominated by diatoms, which live in the near-surface waters of the photic zone, whereas radiolarians are dominant in most pelagic regions during the Eocene. Moreover, the average weight of radiolarian tests of Eocene species was four to five times heavier than the weight of the tests of late Neogene species [Moore, 1969]. These observations suggest an Eocene marine ecology that was quite different from the Neogene.

[25] The deep waters of the Eocene ocean were as much as $10^{\circ} \mathrm{C}$ warmer than deep waters of the modern ocean [Zachos et al., 2001]. Consequently, the density stratification of the Eocene ocean was probably weaker than today's. Zonal wind intensities probably were less intense than in modern times, because of a weaker pole-to-equator thermal gradient [Janecek and Rea, 1983; Janecek, 1985; Rea et al., 


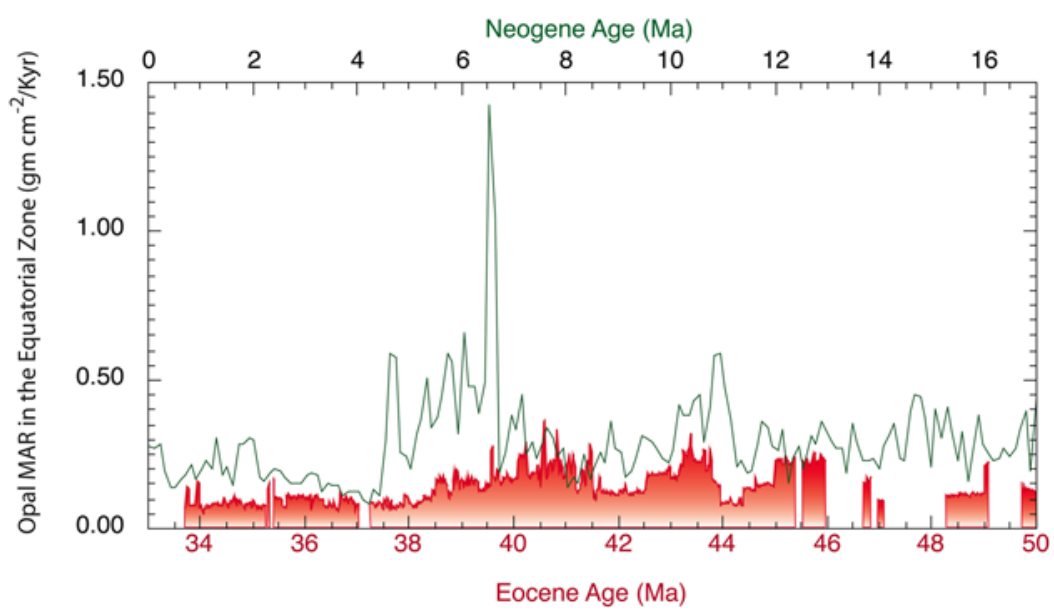

Figure 9. Opal MAR for $0-17 \mathrm{Ma}$ in the Neogene eastern equatorial Pacific (solid line) (data from Farrell et al. [1995]) and for 33.7-50 Ma (from Figure 5) in the Eocene eastern equatorial Pacific (shaded red).

1985; Hovan and Rea, 1992]. Weaker trade winds in the Pacific are also indicated by the lack of sharply defined patterns of equatorial divergence (as indicated by regional sediment accumulation rate patterns) in the warmest part of the Eocene (48-56 Ma) [Moore et al., 2004]. Weakened trade winds in the Pacific have yet to be demonstrated in efforts to model the Eocene [e.g., Huber, 2002], but other modeling efforts do suggest a highly variable strength of the Eocene Trades similar to El Niño-like fluctuations [Huber and Caballero, 2003].

[26] Olivarez Lyle and Lyle [2005, 2006] have pointed out that with an Eocene global ocean temperature some $10^{\circ} \mathrm{C}$ warmer than today, the basal metabolic rate of the oceanic biota in deeper waters was probably twice that of today. Thus, the recycling of nutrients in the ocean was much faster and the delivery and burial of organic carbon to the sea floor was substantially reduced, as was shown by Olivarez Lyle and Lyle [2005, 2006]. The other result of this enhanced nutrient recycling was probably an increase in the dissolved nutrient concentrations of ocean waters below the photic zone.

[27] This leaves us with a somewhat paradoxical view of the Eocene oceans, in which the waters below the nutricline were indeed silica-rich (as silica behaves as a nutrient in the oceans), but with comparatively weak trade winds to bring recycled nutrients to the surface, the diatoms were at a disadvantage. The radiolarians, however, which can live at depth and migrate in the water column, had plenty of silica available to form tests. In the modern oceans radiolarian assemblages living in cooler waters with relatively high concentrations of dissolved silica generally have more robust tests than those living in more tropical, reducedsilica waters; thus, the robust tests of Eocene radiolarians are consistent with the idea that higher metabolic rates resulting from higher temperatures would have resulted in high levels of dissolved silica (along with other nutrients) beneath the nutricline. In Oligocene and younger times the phytoplankton species usually dominate the flux of biogenic silica and carbonate to the seafloor. But in this Eocene ocean, the radiolaria dominate the biogenic silica flux to the sea floor, and the average rate of supply of the Eocene biogenic silica to the sea floor from these zooplankton species was substantially less than in the younger times when silica flux was dominated by phytoplankton.

[28] The question of how and to what degree the formation of cherts affect the preserved record of biogenic silica deposition has yet to be answered. In their survey of Cenozoic cherts, Muttoni and Kent [2007] support chert formation during the Eocene by direct chemical precipitation or adsorption mechanisms. If this model has any validity, then the impact of chert formation on Eocene biogenic silica accumulation rates would be minimal. For both the Neogene and the Eocene, we have avoided using measurements of biogenic silica from both intervals of chert precipitation and intervals of biogenic silica dissolution and assume that there was a "regional balance" between such dissolution and precipitation as suggested by the hydrothermal mechanism of chert formation proposed by Moore [2008].

[29] The Eocene Pacific was probably a "silica-rich" ocean; however, there is no need to call upon a substantial increase in dissolved silica supply from external sources such as volcanism or continental weathering to account for this "richness". In fact, if the tropical Pacific can be taken as representative of the world ocean, an assumed steady state balance between silica input and silica deposition would suggest that the silica supply to the Eocene ocean was less than in more modern times.

\subsection{Maxima in Biogenic Silica Accumulation Rates}

[30] Several distinct maxima occur in the biogenic silica MAR in both the Eocene and the Neogene records (Figures 5 and 9). In their studies of carbonate and organic carbon in the middle through upper Eocene sections of ODP Sites 1218 and 1219, Olivarez Lyle and Lyle [2005, 2006] showed that peaks in organic carbon MAR coincided with CAE 3 (ESAE 5) and CAE 4 (ESAE 6), which they interpreted as peaks in organic productivity. The coincidence of maxima in organic carbon MAR and biogenic silica MAR in some instances may also be associated with 
increased productivity at the equatorial divergence, particularly in the eastern tropical Pacific. This enhanced productivity is logically associated with either increased strength of the trade winds that drive the divergence or with changes in the nutrient content of the shallow intermediate waters that upwell.

[31] It is tempting to try and relate all of the small and large peaks in biogenic silica MAR with climatically induced cycles in paleoproductivity; however, spectral analyses of the opal percent data and of the biogenic silica MAR data (34-46 Ma; Figure 5) show a very broad spectral peak centered at a period of about $3 \mathrm{Ma}$, with no significant peaks in the data. Given the sample resolution of $\sim 20 \mathrm{Ka}$ we might have expected to see eccentricity periods if they were present in the data. No attempt was made to "tune" the data. It still may be that the observed peaks in biogenic silica MAR are related to varying, climatically controlled oceanographic conditions; however, we are only beginning to understand the oceanography of the Eocene warm period, and errors in both timescale and opal measurements may be obscuring the climatic "heartbeat" that governs much of the Cenozoic pelagic record [Pälike et al., 2006, 2001; Pälike and Shackleton, 2000; Shackleton et al., 1999]. The fact that the major peaks in biogenic silica MAR are widely and irregularly separated in time (2-4 Ma; Table 1) may indicate that there are other factors important to the evolution of Eocene climate. Changes in gateway morphology and the locus of deep and intermediate water formation could come into play over such time periods. Both of these factors might affect the richness of upwelled waters and preservation of biogenic silica, but the oscillatory nature of these rate changes, particularly on the shorter timescales, seems more likely to be allied to oscillatory changes in Eocene paleoceanography.

[32] The lower Eocene record is not well recovered, but what has been recovered suggests that biogenic silica MAR in this interval may not have been greatly different from the rest of the Eocene. The main reason for the poor recovery was the presence of cherts in the section. In addition, hydrothermal flow in the upper oceanic crust appears to have removed the siliceous microfossils from the lower 40 $50 \mathrm{~m}$ of the section in many places. Certainly no biogenic silica was found in the basal carbonate section that lies on 56 Ma basaltic basement in nearly all of the ODP Leg 199 sites. However, above the level at which hydrothermal waters have altered the biogenic component of the section, there is clear evidence for peaks in biogenic silica MAR that are twice that of background values: at least in the uppermost part of the lower Eocene.

\subsection{The 38.5 Ma Step in Biogenic Silica MAR}

[33] This step lies just below the top of C18n.1n and at the younger edge of ESAE 6. Changes in the background values of biogenic silica MAR through the Eocene could be associated either with long-term changes in the nutrient supply to the equatorial divergence or with changes in the fractionation of biogenic silica preserved in pelagic sediments from one ocean basin to another. Maps of average sediment accumulation rate (Figures 6 and Figures 7) indicate that the drop in biogenic silica flux at $38.5 \mathrm{Ma}$ in the equatorial sites is reflected in sediment accumulation rates throughout the eastern tropical Pacific. In contrast, sediment accumulation rates west of about $135^{\circ} \mathrm{W}$ are just as high, and perhaps higher, in the younger interval. Such a shift in accumulation rate patterns within the same basin argues against a basin-to-basin fractionation effect.

[34] At times both before and after $38.5 \mathrm{Ma}$, the zone of equatorial divergence remains well defined; yet turnover in the radiolarian assemblage at $38.5 \mathrm{Ma}$ (Figure 8) suggests that there were substantial changes in the ecology of this zone. The largest changes in accumulation rate occur in the eastern tropical Pacific, where the influences of both the flow through the Panamanian gateways and the equatorward flow of the eastern boundary currents were most strongly felt. The implication of this change is that it was the nutrient content of the advected upwelled waters that changed; either from the boundary currents or through the Panamanian gateways [Huber and Sloan, 2000]. However, the direct causal links between a diminution of the sediment accumulation rates in the eastern tropical Pacific and climatic and gateway evolution are not at all clear. The marked change in the radiolarian assemblage suggests that whatever the cause, it was more likely a result of circulation changes affecting surface and shallow intermediate waters than a simple change in productivity of the near-surface waters.

\subsection{Possible Fractionation Effects in Eocene Biogenic Silica Distribution}

[35] In modern times biogenic silica is preserved primarily in a few select regions, the equatorial Pacific being one of those regions. The modern patterns of silica-rich deposition in the Southern Ocean and far North Pacific are mostly Neogene in age. Our knowledge of the amounts of silica preserved in other regions of the Eocene world ocean is limited. Cervato and Burckle [2003] clearly show that most of the evolution of the open ocean diatom flora of the Eocene was focused in the Southern Ocean, which suggests that the diatom flora was sparse (or very poorly preserved) in both tropical and high northern latitudes of the Atlantic and Pacific Oceans.

[36] Quantitative knowledge of possible basin-to-basin fractionation of biogenic silica deposition is hampered by the paucity of Eocene records from these higher latitudes and almost no records of true flux rates. Such fractionation effects are as yet speculative. Similarly, we do not have a quantitative understanding of Eocene biogenic silica flux rates in shallow waters. Evidence for a contrast in open ocean versus near-shore primary productivity has been found for the interval of extreme warmth marking the PaleoceneEocene boundary [Gibbs et al., 2006]. The upper Eocene diatomites of the Chira Formation and Fundo Desbarrancado section in northern Peru [Marty et al., 1988] may be a good example of such siliceous-rich sediments deposited in a near shore, upwelling region. Although biogenic debris deposited in shallow waters are subject to rapid recycling, if the shallow seas of the Eocene were a significant sink for biogenic silica, the total Eocene biogenic silica MAR could have been more similar to that of the Neogene.

[37] Little if any biogenic silica has been recovered in Eocene sections from the North Pacific and South Atlantic 


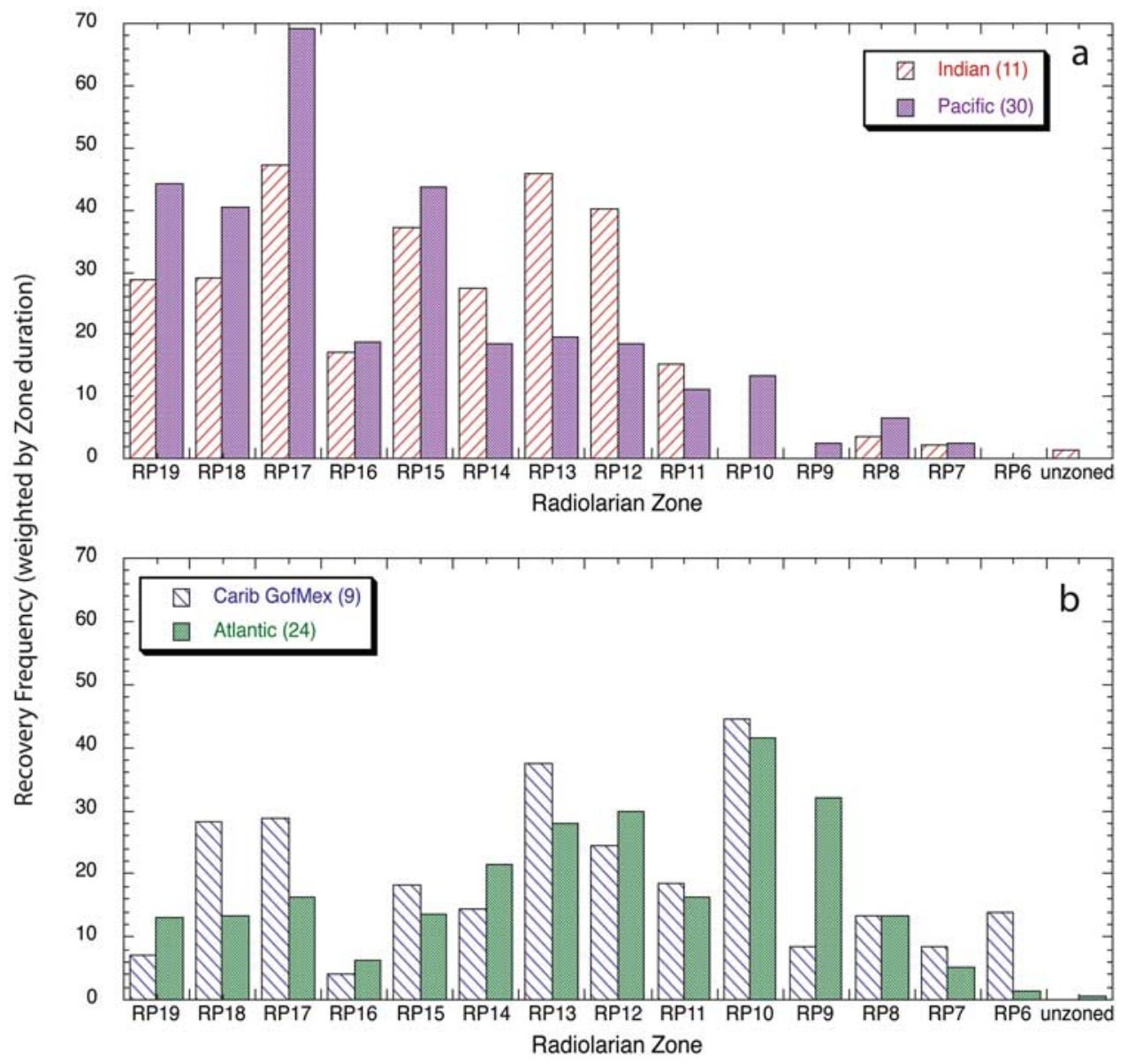

Figure 10. Frequency of the recovery of Eocene radiolarian zones from (a) the Pacific and Indian Ocean basins and (b) the Atlantic Ocean and Caribbean Sea basins (from A. Sanfilippo and C. Nigrini, personal communication). The number of sites that penetrated the Eocene in each basin is shown in parentheses in the legends. Values are expressed as the percent of the Eocene sites in each basin recovering each zone, divided by the duration of each zone in Ma (cf. Figure 5).

open ocean basins. There are some regions of the Atlantic Ocean in which Eocene biogenic silica was preserved but where none is being preserved today. In the North Atlantic, Tucholke and Mountain [1979] identified acoustic reflector " $\mathrm{A}$ " as being associated with cherts and radiolarian-rich turbidites near the lower middle Eocene boundary ( $\sim 49 \mathrm{Ma}$ ) and indicate that this reflector usually varies in age by no more than $4 \mathrm{Ma}$ [Tucholke, 1981]. This layer and its associated turbidites are close in age to perhaps the biggest sea level falls of the Eocene [Haq et al., 1987], estimated to be $\sim 25 \mathrm{~m}$ at $47 \mathrm{Ma}, \sim 25 \mathrm{~m}$ at $49 \mathrm{Ma}$ and $\sim 80 \mathrm{~m}$ at $50.6 \mathrm{Ma}$ [Miller et al., 2005]. This causes us to suspect that the radiolarians of this layer may have been transported (and hydraulically concentrated) from the broad shelves and slopes that surrounded the Eocene North Atlantic.

[38] Reflector $A^{c}$ is a pervasive feature in the North Atlantic, and as mapped [Tucholke, 1981] it covers an area of almost $3 \times 10^{6} \mathrm{~km}^{2}$. This is less than half the area of biogenic silica deposition in the Pacific equatorial zone of about $7.4 \times 10^{6} \mathrm{~km}^{2}$. In their review of North Atlantic pelagic sediments, Thiede et al. [1981] note only one brief time when the concentration of biogenic silica reached $20 \%$ in the Cenozoic pelagic sediments: between $\sim 42$ and $53 \mathrm{Ma}$. This is about the same age as the siliceous deposits associated with reflector $\mathrm{A}^{\mathrm{c}}$. The sedimentation rates shown graphically by Thiede et al. [1981] for this time interval range between $<0.5$ and $1 \mathrm{~cm} / \mathrm{Ka}$. Assuming an estimated sediment dry bulk density of about $1.2 \mathrm{~g} \mathrm{~cm}^{-3}$, the biogenic silica MAR during this North Atlantic peak in biogenic silica concentrations would be no more than $\sim 0.24 \mathrm{~g} / \mathrm{cm}^{2} / \mathrm{Ka}$. These data are not strictly comparable to those presented here for the Pacific because detailed time series of measurements were not taken and the data are only presented as contoured values on a plot of depth versus age; however, the maximum values indicated by these plots are comparable to peak rates for ESAE 1 through 4 at about this same time in the equatorial Pacific (Table 1 and Figure 5). These comparisons of silica fluxes and the relative size of the two areas indicate that the North Atlantic is not likely to have dominated the silica budget in the Eocene. The tropical Pacific Ocean was likely one of the largest of the siliceous depocenters throughout the Cenozoic.

[39] Even if the tropical Pacific was the dominant biogenic silica depocenter in the Eocene, there still may have been 
some degree of basin-to-basin fractionation of biogenic silica that offset the low sedimentation in the Pacific equatorial region. The problem is a lack of reliable biogenic silica MARs for other ocean basins with which to make comparisons. We do have data on the ages of siliceous Eocene sediments recovered from the ocean basins during DSDP and ODP drilling. In Figure 10 we show the normalized frequency of occurrence of radiolarian zones in the Indian and Pacific Oceans (Figure 10a) compared to the recovery of these zones in the Atlantic Ocean and Caribbean Sea (Figure 10b). The values in Figure 10 represent the percent of the sites in each basin that have penetrated the Eocene and recovered sediments from each radiolarian zone, divided by the duration of each zone in Ma. In the Atlantic and Caribbean (Figure 10b) we see a fairly high rate of recovery of radiolarian zones RP9 through RP11, which coincides with the approximate span of age estimates for reflector $A^{c}$ (cf. Figure 5). In general the radiolarian zones of the lower part of the Eocene are better recovered in the AtlanticCaribbean, whereas those of the upper Eocene are better recovered in the Pacific-Indian sector. Deposits containing radiolarians from the lowermost Eocene and Paleocene are not well represented in any of the basins thus far studied. These data suggest that the Atlantic-Caribbean basins may have a better preserved record of the earlier part of the Eocene than the Pacific-Indian basins. These differences may reflect some degree of basin-to-basin fractionation. For example, $\mathrm{Nd}$ isotopes suggest that bottom waters were being formed in the North Pacific during the Paleocene and Eocene (up to $\sim 43 \mathrm{Ma}$ ) [Thomas, 2004], a result that is consistent with large-scale sedimentation patterns. The paucity of Eocene siliceous deposits in the North Pacific (the presumed origin of deep water, formed from low-silica surface waters) and the preservation of siliceous deposits in the North Atlantic and Caribbean (a presumed terminus of the flow of bottom waters relatively rich in dissolved silica) is a pattern that would be expected to result from this flow of deep waters. These sedimentation patterns changed when the primary locus of bottom water formation shifted to the Southern Ocean [Thomas, 2004], with the recovery frequency of radiolarian zones dropping in the Atlantic sector to between 10 and 20 (Figure 10b) while recovery frequency in the Pacific rose to generally $>40$ between radiolarian zones RP14 and RP15 ( 40$43 \mathrm{Ma})$.

[40] In the Eocene open oceans we have evidence for biogenic silica deposition only in the tropical Pacific and Indian Oceans, the Southern Ocean, the Caribbean Sea, and in the North Atlantic ( $\sim 22-52 \mathrm{Ma})$. In more modern times silica is being deposited in the tropical Pacific and Indian Oceans, the North Pacific, and the Southern Ocean. We do not have reliable data on the flux of biogenic silica in all these areas, but based solely on the area of coverage, the modern ocean has a greater prevalence of siliceous deposits than does the Eocene. The tropical Pacific has been a major depocenter for biogenic silica throughout the Cenozoic, and the Eocene MAR of biogenic silica in this region was substantially less than in the Neogene. Thus, we can at least question the dogma that the siliceous-rich nature of the Eocene marine deposits requires an additional or enhanced source of silica being supplied to the oceans [McGowran, 1989, and references therein].

[41] Acknowledgments. We would like to thank the Ocean Drilling Program for providing samples and the officers, crew, staff, and scientists who sailed on Legs 138 and 199 whose efforts made this research possible. We thank Michael Vanden Berg for his Leg 199 opal estimates, based on multisensor track data and visible and near-infrared spectroscopy data. We would also like to thank the reviewers of this paper for their constructive and helpful suggestions. Support for this research was provided by JOI/ USSAC and by the National Science Foundation grant OCE-0725301 to Lyle and Olivarez Lyle.

\section{References}

Berggren, W. A., and C. D. Hollister (1974), Paleogeography, paleobiogeography and the history of circulation in the Atlantic Ocean, in Studies in Paleoceanography, edited by W. W. Hay, Spec. Publ. Soc. Econ. Paleontol. Mineral, 20, 126-186.

Bohaty, S., and J. Zachos (2003), Significant Southern Ocean warming event in the late middle Eocene, Geology, 31, 1017-1020.

Cande, S. C., and D. V. Kent (1995), Revised calibration of the geomagnetic polarity time scale for the Late Cretaceous and Cenozoic, J. Geophys. Res., 100, 6093-6095.

Cervato, C., and L. Burckle (2003), Pattern of first and last appearance in diatoms: Oceanic circulation and the position of polar fronts during the Cenozoic, Paleoceanography, 18(2), 1055, doi:10.1029/2002PA000805.

Farrell, J. W., I. Raffi, T. Janecek, D. Murray, M. Levitan, K. Dadey, K. C. Emeis, M. Lyle, and J. Abel (1995), Evolution of late Neogene sedimentation patterns in the eastern equatoria Pacific Ocean (Leg 138), Proc. Ocean Drill. Program Sci. Results, 138, 717-756.

Funakawa, S., H. Nishi, T. C. Moore, and C. A. Nigrini (2006), Radiolarian faunal turnover and paleoceanographic change around Eocene/Oligocene boundary in the central equatorial Pacific, ODP Leg 199, Holes 1218A, 1219A, and 1220A, Palaeogeogr Palaeoclimatol. Palaeoecol., 230, $183-$ 203.

Gibbs, S. J., T. J. Bralower, P. R. Bown, J. C. Zachos, and L. M. Bybell (2006), Shelf and open-ocean calcareous phytoplankton assemblages across the Paleocene-Eocene therma maximum: Implications for global productivity gradients, Geology, 34, 233-236.

Gibson, T. G., and K. M. Towe (1971), Eocene volcanism and the origin of the Horizon A, Science, 172, 152-154.

Haq, B. U., J. Hardenbol, and P. R. Vail (1987) Chronology of fluctuating sea levels since the Triassic, Science, 235, 1156-1167.

Herman, Y. (1972), Origin of deep sea cherts in the North Atlantic, Nature, 238, 392-393.

Hovan, S. A., and D. K. Rea (1992), Paleocene/ Eocene boundary changes in atmospheric and ocean circulation: A Southern Hemisphere record, Geology, 20, 15-18.

Huber, M. (2002), Straw man 1: A preliminary view of the tropical Pacific from a global coupled climate model simulation of the early Paleogene, Proc. Ocean Drill. Program Initial Rep. [CD-ROM], 199, 1-30.

Huber, M., and R. Caballero (2003), Eocene El Niño: Evidence for robust tropical dynamics in the "hothouse", Science, 299, 877-881.

Huber, M., and L. C. Sloan (2000), Modeling the Paleogene: part II. Paleogene wind driven ocean circulation changes predicted from climate modeling studies, in Early Paleogene Warm Climates and Biosphere Dynamics. Short Papers and Extended Abstracts, edited by B. Schmitz, B. Sundquist, and F. Andreasson, GFF, 122(1), 80-81.

Janecek, T. R. (1985), Eolian sedimentation in the northwest Pacific Ocean: A preliminary examination of data from deep sea drilling sites 576 and 578, Initial Rep. Deep Sea Drill. Proj., 86, 509-683.

Janecek, T. R., and D. K. Rea (1983), Eolian deposition in the northeast Pacific Ocean: Cenozoic history of atmospheric circulation, Geol. Soc. Am. Bull., 94, 730-738.

Lanci, L., J. M. Parés, J. E. T. Channell, and D. V. Kent (2005), Oligocene magnetostratigraphy from equatorial Pacific sediments 
(ODP Sites 1218 and 1219 Leg 199), Earth Planet. Sci. Lett., 237, 617-634.

Leinen, M. (1979a), Biogenic silica accumulation in the central equatorial Pacific and its implications for Cenozoic paleoceanography: Summary, Geol. Soc. Am. Bull., 90, 801-803.

Leinen, M. (1979b), Biogenic silica accumulation in the central equatorial Pacific and its implications for Cenozoic paleoceanography: part II, Geol. Soc. Am. Bull., 90, 1310-1376.

Lyle, M., et al. (2002), Proceedings of the Ocean Drilling Program Initial Reports [CD-ROM], 199, Ocean Drill. Program, College Station, Tex.

Lyle, M., A. Olivarez Lyle, J. Backman, and A. Tripati (2005), Biogenic sedimentation in the Eocene equatorial Pacific: The stuttering greenhouse and Eocene carbonate compensation depth, Proc. Ocean Drill. Program Sci. Results, 199, 1-35.

Marty, R., R. Dunbar, J. B. Martin, and P. A. Baker (1988), Late Eocene diatomite from the Peruvian coastal desert, coastal upwelling in the eastern Pacific, and Pacific circulation before the terminal Eocene event, Geology, $16,818-822$

Mattson, P. H., and E. A. Pessagno Jr. (1971), Caribbean Eocene volcanism and the extent of Horizon A, Science, 174, 138-139.

Mayer, L., et al. (1992), Proceedings of the Ocean Drilling Program Initial Reports, 138, Ocean Drill. Program, College Station, Tex

McGowran, B. (1989), Silica burp in the Eocene ocean, Geology, 17, 857-860.

Miller, K. G., M. A. Kominz, J. V. Browning, J. D. Wright, G. S. Mountain, M. E. Katz, P. J. Sugarman, B. S. Cramer, N. Christie-Blick, and S. F. Pekar (2005), The Phanerozoic record of global sea-level change, Science, $310,1293-1298$

Moore, T. C., Jr. (1969), Radiolaria: Change in skeletal weight and resistance to solution, Geol. Soc. Am. Bull., 80, 2103-2108.

Moore, T. C., Jr. (2007), Cherts in the Pacific: Biogenic silica and hydrothermal circulation, Palaeogeogr. Palaeoclimatol. Palaeoecol., in press.

Moore, T. C., Jr., J. Backman, I. Raffi, C. Nigrini, A. Sanfilippo, H. Pälike, and M. Lyle (2004) The Paleogene tropical Pacific: Clues to circulation, productivity and plate motion, Paleoceanography, 19, PA3013, doi:10.1029, 2003PA000998.

Mortlock, R. A., and P. N. Froelich (1989), A simple method for the rapid determination of biogenic opal in pelagic marine sediments, Deep Sea Res., Part A, 36, 1415-1426.

Muttoni, G., and D. V. Kent (2007), Widespread formation of cherts during the early Eocene climate optimum, Palaeogeogr. Palaeoclimatol. Palaeoecol., 253, 348-362, doi:10.1016/ j.palaeo.2007.06.008.

Nigrini, C., A. Sanfilippo, and T. C. Moore Jr (2006), Cenozoic radiolarian biostratigraphy:
A magnetobiostratigraphic chronology of Cenozoic sequences from ODP Sites 1218 1219, and 1220, equatorial Pacific, Proc. Ocean Drill. Program Sci. Results, 199, 1-76.

Olivarez Lyle, A., and M. Lyle (2002), Determination of biogenic opal in pelagic marine sediments: A simple method revisited, Proc. Ocean Drill. Program Initial Rep. [CD-ROM], 199 $1-21$.

Olivarez Lyle, A., and M. Lyle (2005), Organic carbon and barium in Eocene sediments: possible controls on nutrient recycling in the Eocene equatorial Pacific Ocean, Proc. Ocean Drill. Program Sci. Results, 199, 1-33.

Olivarez Lyle, A., and M. Lyle (2006), Missing organic carbon in Eocene marine sediments: Is metabolism the biological feedback that maintains end-member climates? Paleoceanography, 21, PA2007, doi:10.1029/2005PA001230

Pälike, H., and N. J. Shackleton (2000), Constraints on astronomical parameters from the geological record for the last $25 \mathrm{Myr}$, Earth Planet. Sci. Lett., 182, 1-14.

Pälike, H., N. J. Shackleton, and U. Röhl (2001), Astronomical forcing in late Eocene marine sediments, Earth Planet. Sci Lett., 193, 589-602.

Pälike, H., R. D. Norris, J. O. Herrle, P. A. Wilson, H. K. Coxall, C. H. Lear, N. J. Shackleton, A. K. Tripati, and B. S. Wade (2006), The heartbeat of the Oligocene climate system, Science, 214, 1894-1898.

Parés, J. M., and L. Lanci (2004), A complete middle Eocene-early Miocene magnetic polarity stratigraphy in equatorial Pacific sediments (ODP Site 1220), in Timescales of the Paleomagnetic Field, vol. 145, edited by J. E. T. Channell et al., pp. 131-140, AGU, Washington, D. C

Parés, J. M., and T. C. Moore (2005), New evidence for the Hawaiian Hotspot plume motion since the Eocene, Earth Planet Sci Lett., 237, 951-959.

Pisias, N. G., L. A. Mayer, and A. C. Mix (1995), Paleoceanography of the eastern equatorial pacific during the Neogene: Synthesis of Leg 138 drilling results, Proc. Ocean Drill. Program Sci. Results, 138, 5-31.

Rea, D. K., and M. W. Lyle (2005), Paleogene calcite compensation depth in the eastern subtropical Pacific: Answers and questions, $\mathrm{Pa}$ leoceanography, 20, PA1012, doi:10.1029/ 2004PA001064

Rea, D. K., M. Leinen, and T. R. Janecek (1985), Geologic approach to the long-term history of atmospheric circulation, Science, $227,721-725$

Shackleton, N. J., S. J. Crowhurst, G. P. Weedon, and J. Laskar (1999), Astronomical calibration of Oligocene-Miocene time, Philos. Trans. $R$. Soc. Ser. A, 357, 1907-1929.

Thiede, J., J. E. Strand, and T. Agdestein (1981), The distribution of major sediment components in the Mesozoic and Cenozoic North Atlantic Ocean, in The Deep Sea Drilling Pro- ject: A Decade of Progress, edited by J. E. Warme, R. G. Douglas, and E. L. Winterer Spec. Publ. Soc. Econ. Paleontol. Mineral. 32, 67-90.

Thomas, D. J. (2004), Evidence for deep-water production in the North Pacific Ocean during the early Cenozoic warm interval, Nature, 430, 65-68.

Tucholke, B. E. (1981), Geologic significance of seismic reflectors in the deep western North Atlantic basin, in The Deep Sea Drilling Project: A Decade of Progress, edited by J. E. Warme, R. G. Douglas, and E. L. Winterer, Spec. Publ. Soc. Econ. Paleontol. Mineral., 32, 23-38

Tucholke, B. E., and G. S. Mountain (1979), Seismic stratigraphy, lithostratigraphy and paleosedimentation patterns in the North American basin, in Deep Drilling Results in the Atlantic Ocean: Continental Margins and Paleoenvironment, edited by M. Talwani, W. Hay, and W. B. F. Ryan, M. Ewing Ser., vol. 3 , pp. 58-85, AGU, Washington, D. C.

van Andel, T. H., G. R. Heath, T. C. Moore Jr. (1975), Cenozoic History and Paleoceanography of the Central Equatorial Pacific Ocean, Mem. Geol. Soc. Am., 143, 134 pp., Geol. Soc. of Am., Boulder, Colo.

van Andel, T. H., J. Thiede, J. G. Sclater, and W. W. Hay (1977), Depositional history of the South Atlantic Ocean during the last 125 million years, J. Geol., 85(6), 651-698.

Vanden Berg, M. D., and R. D. Jarrard (2002), Determination of equatorial Pacific mineralogy using light absorption spectroscopy, Proc. Ocean Drill. Program Initial Rep. [CDROM], 199, 1-20.

Vanden Berg, M. D., and R. D. Jarrard (2004), Cenozoic mass accumulation rates in the equatorial Pacific based on high-resolution mineralogy of ODP Leg 199, Paleoceanography, 19, PA2021, doi:10.1029/2003PA000928.

Vanden Berg, M. D., and R. D. Jarrard (2006), Data report: High-resolution mineralogy for Leg 199 based on reflectance spectroscopy and physical properties, Proc. Ocean Drill. Program Sci. Results, 199, 1-23.

Zachos, J. C., M. Pagani, L. Sloan, E. Thomas, and K. Billups (2001), Trends, rhythms, and aberrations in global climate 65 Ma to present, Science, 292, 686-693.

R. D. Jarrard, Department of Geology and Geophysics, University of Utah, Salt Lake City, UT 84112-0111, USA

T. C. Moore Jr., Department of Geological Sciences, University of Michigan, Ann Arbor, MI 48109-1005, USA.

M. Lyle and A. Olivarez Lyle, Department of Oceanography, Texas A\&M University, 3146 TAMU, College Station, TX 77843-3146, USA 